\title{
Swot analysis of dry toilets
}

\author{
J. Nagy \& A. Zseni \\ Széchenyi István University, Hungary
}

\begin{abstract}
The aim of our study is to give an assessment of the dry toilets by evaluating their strengths, weaknesses, opportunities and threats. More and more environmentalists consider the use of dry toilets as the solution for solving the problems caused by the utilization of flush toilets. With the application of flush toilet, in addition to its harmful environmental effects and to the high water consumption of toilet, the nutrients in the human excreta are wasted. However, there are some misconceptions about the environmental effects of dry toilets, and we are not aware of the fact, that some type of dry toilets also has unfavourable environmental effects. SWOT analysis is an initialism for strengths, weaknesses, opportunities, and threats. It can be carried out not only for projects and a business venture, but also for a product or a technical solution. With the application of SWOT analysis we assessed and compared the different types of dry toilets by evaluating the above mentioned four elements of them. We evaluate the incinerating toilets and the two main groups of composting toilets: types which treat the human faeces and urine together and types which separate them. A third type, the so-called microflush toilets is also examined. Identification of strengths, weaknesses, opportunities and threats is important because they can inform later steps in planning to achieve the objective: which methods and technical solutions are the best for our environment. We are convinced that the best technical solution is, which allows the composting of human excreta in order to recirculate it to the cycle of biosphere.
\end{abstract}

Keywords: dry toilets, strengths, weaknesses, opportunities, threats, SWOT analysis, composting toilet, incinerating toilet, microflush toilet, flush toilet.

\section{Introduction}

Various methods and techniques has been used for collection and removal of human excreta, and these methods and techniques has changed according to 
historical times and places. In $201568 \%$ of the global population ( 5 billion people) use an improved sanitation facility ( $82 \%$ of the global urban population, and $51 \%$ of the rural population). Among the 5 billion people 2.8 billion (38\%) have flush/pour flush to piped sewer system, 0.9 billion people have flush/pour flush to septic tanks or pit latrine and 1.3 billion people use ventilated improved pit (VIP) latrine, pit latrine with slab or composting toilet. In 2015, 2.4 billion people still lack improved sanitation facilities: they have to share sanitation facilities, or have unimproved sanitation facilities (pit latrines without a slab or platform, hanging latrines and bucket latrines), or have to practice open defecation. It is estimated that 638 million people worldwide share sanitation facilities of an otherwise improved type in 2015. Almost 950 million people (13\%) still practice open defecation. Seven out of ten people without improved sanitation facilities, and nine out of ten people still practicing open defecation, live in rural areas. (UNICEF and WHO [1]).

In present days, flush toilets have spread in our developed world, but with the application of flush toilet, in addition to its harmful environmental effects and its high water consumption, the nutrients in the human excreta are wasted. Their operation and maintenance need cost and energy and they cause water pollution. It would be more reasonable to use human excreta for agricultural purposes, also because the basic materials of the artificial fertilizer will be exhausted. It is not a new idea to use human excreta for agricultural purposes, rather it was - some place now still is - part of everyday life. The method of utilization basically can be two types: we collect and use faeces and urine together, or we separate them. The requirement of proper use is to separate the collected excreta from the water supply network - for this objective more solutions exist, prevalent or spread, for instance traditional latrines, modern dry toilets, or separating toilets. In our study we present these toilet types and evaluate them and their environmental effects with the help of SWOT analysis.

SWOT analysis is an acronym for strengths, weaknesses, opportunities and threats. SWOT is a structured planning method that evaluates the four elements of a project or business venture. It can be carried out for a company, product, place, industry or person, as well. The technique is assigned to Albert Humprey, who led a research project at Stanford University in the 1960s and 1970s using data from Fortune 500 companies (Arslan and Er [2]). Strengths are inside factors, positive things, which are function well, and we may have influence to make it even better. Weaknesses are inside factors, those things which are not function well, but we may have influence to make it better. Opportunities are outside factors, facilities we do not have effect on, but they are prosperous and building on them we can prove our strengths. Threats are outside factors, limits, negative factors, mean risks, which we do not have influence on, and they decrease the chance of success.

With SWOT analysis we can know which tasks are the most important from strategic view-point. Internal factors are the strengths and weaknesses internal to the organization. External factors are the opportunities and threats presented by the environment external to the organization (Digital Library [3]). 


\section{Dry toilets}

\subsection{Composting toilets}

Basically dry toilets can be sorted into two groups: composting and incinerating (in other name burning) toilets. We can group composting toilets into two types, the ones handle urine and faeces together, and the other ones which separate them. In our study also a third type, the so-called microflush toilet is examined.

\subsubsection{Types which handle urine and faeces together}

There are several types of composting toilets: for example, the composting toilet of EcoSan [4] and the biolitter toilet of Országh [5]. The basic and primary target of composting toilets which handle faeces and urine together should be to take back the excreta to the soil by creating the most effective humus. Only this type of composting toilet enables the composting process of human excreta. Humus formative processes need ideal $\mathrm{C} / \mathrm{N}$ proportion, so the best solution is to compost excreta with plant biomass (Országh [5]).

In the case of composting toilet of EcoSan, excreta fall down a vertical chute (2), and into one end of a helical screw conveyor (3) (Figure 1).

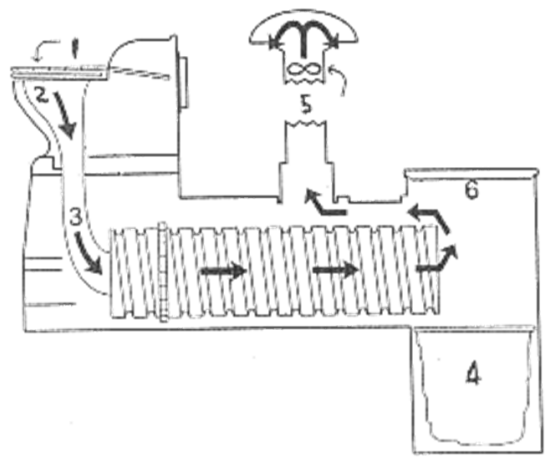

Figure 1: Composting toilet which can handle faeces and urine together (EcoSan [4]).

Every time the toilet lid (1) is lifted, a mechanism rotates the conveyor. With each rotation the excreta slowly move along, taking about twenty-five days before falling into a reusable collection bag (4). It takes six months for the bag to fill with waste. The waste will be dry and odourless. Through the ventilation pipe (5), airflow is provided for the dehydration, evaporation, deodorising process. Human excreta consist of roughly $95 \%$ moisture. The solids dry in the conveyer, the urine and moisture volatilize into the atmosphere. The solid waste then dries into a compost-like material, and it will be roughly $5-10 \%$ of its original mass. So the system breaks down human waste into a dehydrated odourless compost-like material (EcoSan [4]). We can manage the dry waste and process it in the following ways: 
- for agricultural purposes (make compost or natural fertilizer),

- to dispose it by using municipal waste services,

- to use it as a source of fuel,

- to create biogas.

Large objects like beverage cans, disposable nappies or other objects accidentally dropped down the chute will not block the system, it is however not advisable to do this (EcoSan [4]).

The excreta and in small amount also the urine contain trace elements, amongst them heavy metals. However, the amount of them is very small, and heavy metals get into the human organism with food. Because of the small amount of heavy metals, we can use excreta for soil nutrient supplies (Jönsson et al. [6], Schouw et al. [7], Vinnerås et al. [8]).

Depending on the population's health condition, several bacteria, virus, and worm can be found in the excreta. That is why direct contact with fresh excreta always has the danger of infection, even when we know that in healthy, normal intestinal flora the pathogenic microorganisms won't appear. Pathogenic microorganisms for example Aeromas species, the Campylobacter jejuni/coli, the Escherichia coli, the Plesiomonas shigelloides, the Pseudomonas aeruginosa, the Salmonella typhi/paratyphi, other Salmonella species, Shigella species, Vibrio cholerae and Yersinia species. Pathogenic bacteria for example the Enteric adenovirus 40 and 41, the astrovirus, the calicivirus, the Hepatitis $A$ virus, the Hepatitis E virus, the poliovirus and the rotavirus. Parasite protozoa, for example the Cryptosporidium parvum, Cyclospora cayetanensis, Entamobea histolytica, Giardia intestinalis (Schönning and Stenström [9]).

Due to contagion, also urine can contain causative microorganisms (for instance Leptospira interrogans, Salmonella typhi, Salmonella paratyphi, Schistosoma haematobium), but the amount of these are small according to microorganisms appear in excreta (Feachem et al. [10]).

However, microorganism of faeces origin of the properly composted excreta is infinitesimal. Moreover the tape worm eggs will perish during long-lasting composting. For removal of pathogen microorganisms, increase of temperature is a reliable used method. Most of the literature indicates $50-50^{\circ} \mathrm{C}$ for pathogen removal of compost. If the temperature reaches $50^{\circ} \mathrm{C}$ and this status will hold at least for a week, then we reach the inactivity of pathogen microorganisms (Schönning and Stenström, [9]). The more and longer time we overstep the $50^{\circ} \mathrm{C}$, the less time will hold and will be more efficient the sterilization (Niwagaba [11]).

\subsubsection{Separating/no mix toilet}

Separating toilet separates urine and faeces (Figure 2). The urine contains the main part of nitrogen $(88 \%)$, phosphorus $(67 \%)$ and potassium $(73 \%)$ of excreta (Kirchmann and Pettersson [12]). According to Höglund et al. [13] urine is considered sterile, and can be used as a liquid plant fertilizer directly without further treatment. To overcome this problem, a urine diversion (UD) or no mix toilet haven been designed by Larsen et al. [14] to separate human urine at source. UD technology haven been used successfully in many developing and developed countries such as Ethiopia, China, Ecuador, El Salvador, Guatemala, India, 
Mexico, South Africa, Thailand, Vietnam, Zimbabwe, Finland, Sweden and Germany. However, storage and transport of human urine is a crucial part, because several spontaneous processes such as urea hydrolysis, precipitation or volatilization could change the urine composition significantly. It is recommended that storage period should be maximum six months at $20^{\circ} \mathrm{C}$ or higher (Karak and Bhattacharyya [15]).

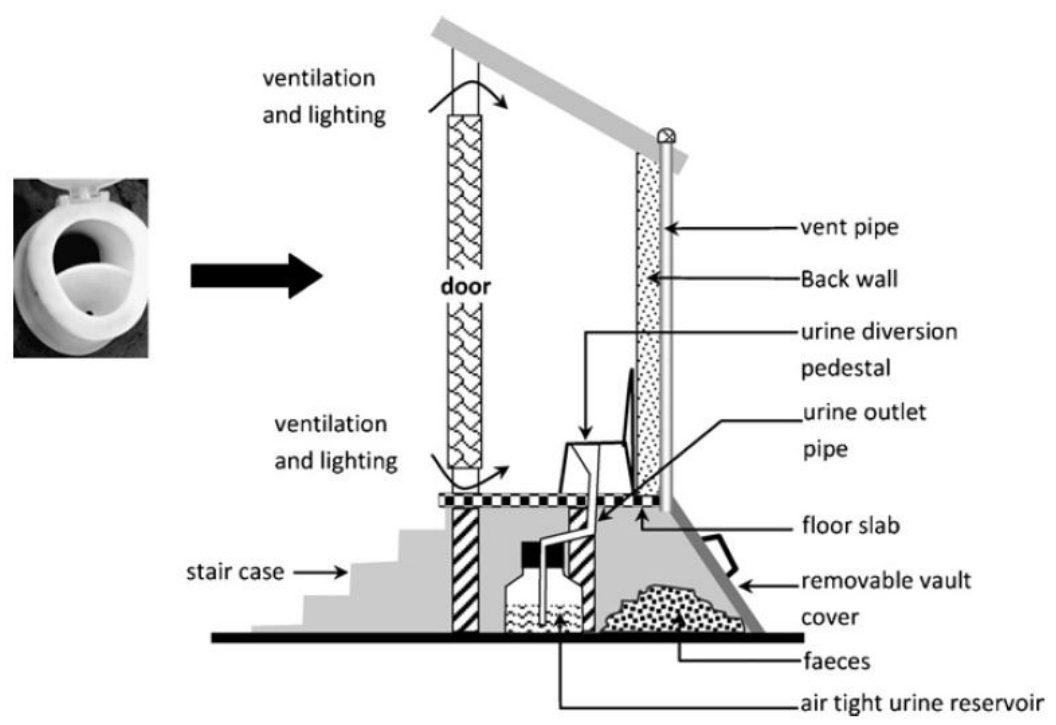

Figure 2: Composting toilet which separate faeces and urine (Karak and Bhattacharyya [15]).

As urine contains the bigger part of nitrogen, phosphorus and potassium content of excreta, research of practical utilization mainly connected to urine. The treatments of urine and its utilizations for nutrient supplying nowadays have significant specialized literature and practice (some examples: Jönsson et al. [16], Maurer et al. [17], Niwagaba [11], Pradhan et al. [18], Richert et al. [19], Wohlsager et al. [20], Semalulu et al. [21], Anderson [22]). Some urine treatment processes depending on further utilization purpose, need to be developed significantly in order to the laboratory experiments become technologies which can produce marketable ware. However, we have to consider that urine converts to ammonium-nitrate solution fast, which is the product of fertilizer manufacturing too, with all the disadvantages of its utilization (and with its undeniable yield increasing effect).

\subsubsection{Microflush toilets}

Stephen Mecca with the help of the Bill and Melinda Gates Foundation created the microflush toilet. The microflush toilet is sustainable, environmentally friendly, odor and fly-free and low cost toilet. The toilet is flushed with grey water 
from the hand wash and resulting small volume of blackwater, a little more than 20 gallons, compared with 500-700 gallons from a standard flush toilet. The system rapidly filters solids in the waste stream from liquids - urine and grey water from hand washing (Figure 3). The toilet valve uses $150 \mathrm{~cm}^{3}$ of the handwash greywater for flushing (Figure 4). The solids are digested and vermi-composted with earthworm Eisenia Fetida and other macro-organisms resulting in high mass reduction and pathogen removal, a process that has proven to be superior to traditional latrine microbial composting. The resulting compost is harvested every $2-3$ years. Toilets are often owned and built near $2-3$ households, so that multiple households can share a toilet, bringing the cost down even more (Mecca et al. [23, 24]). Though microflush toilet may not regarded as a typical dry toilet, because it uses a small amount of water.

\section{Microflush Toilet}

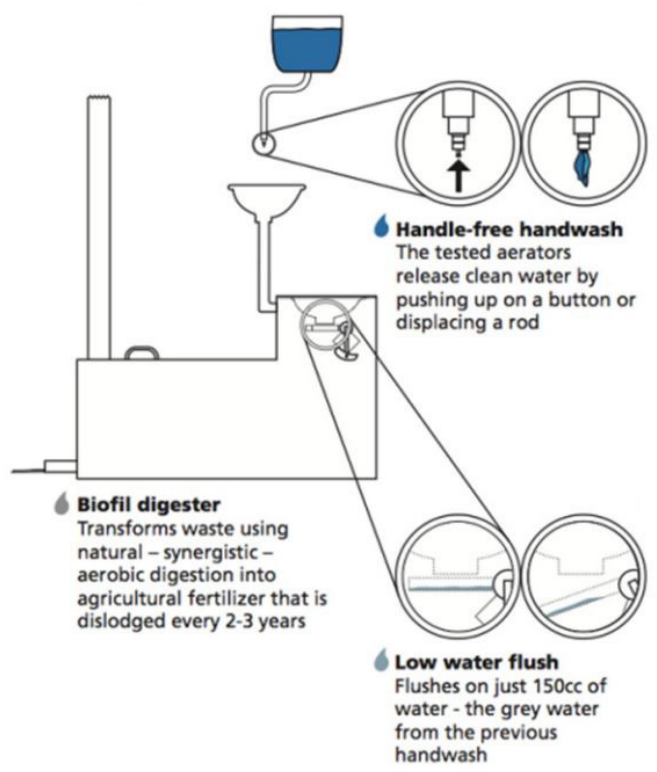

Figure 3: Microflush toilet (Mecca et al. [24]). 

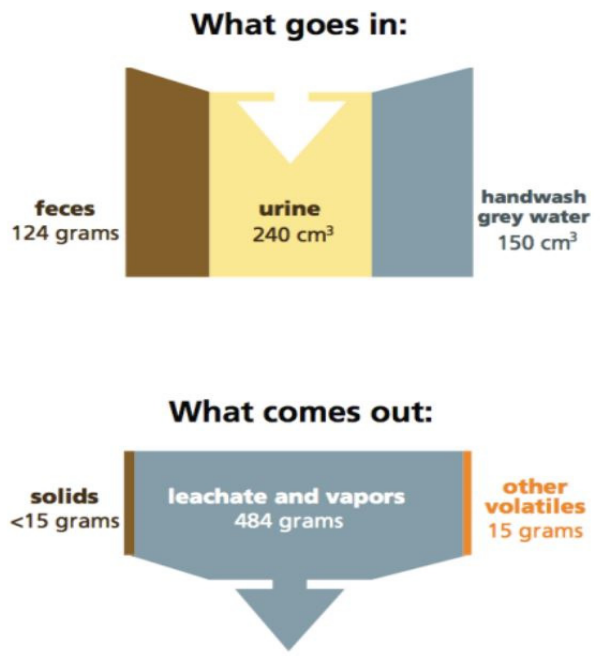

Figure 4: $\quad$ Microflush toilet - mass balance (Mecca et al. [23]).

\subsection{Incinerating toilet}

The incinerating toilet burns human excreta instead of flushing it away with water, like flush toilet does. These types of toilets may be powered by electric, gas, dried faeces or other energy sources. Some types will also incinerate grey and black water created from showers and sinks. The schematic diagram of incinerating toilet is depicted in Figure 5.

The incineration process continues until all of the waste is gone (urine, solids, paper). As a small amount of sterile ash remains, users have to empty the ash

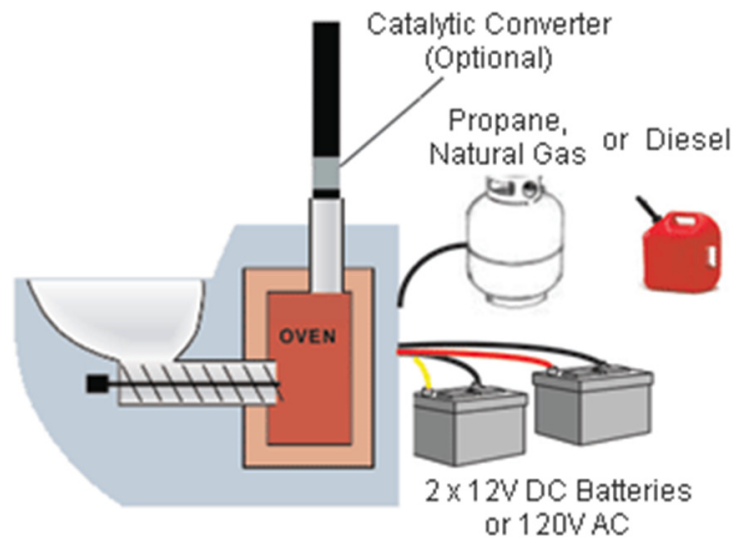

Figure 5: Incinerating toilet (ECOJOHN [25]). 
periodically. The short cycle (for urine) takes about 5-10 minutes, while the long cycle takes 35-40 minutes. The toilets have a built in circuit board that monitors the operations. It also will indicate if the burn cycles have completed, max capacity or any errors happen during the burning process. The toilet remains clean, because waste never touches the bowl surface. A bowl liner in the bowl captures the waste, then both the liner and its content drop into the incinerator chamber when user pushed the foot pedal (ECOJOHN [25], INCINOLET [26]).

\section{Swot analysis of dry toilets}

In Tables 1, 2, 3 and 4 the results of SWOT analysis are summarized.

Table 1: $\quad$ SWOT analysis for EcoSan type composting toilet which can handle faeces and urine together.

\begin{tabular}{|c|c|}
\hline $\begin{array}{l}\quad \text { Strengths } \\
\text { - } \text { low odour levels } \\
\text { - no need for fuel } \\
\text { - } \text { no plumbing required } \\
\text { - no emission } \\
\text { - } \text { easy to install } \\
\text { - } \text { eliminate odours and disease-bearing } \\
\text { flies } \\
\text { - } \text { water free toilet system } \\
\text { - chemical free } \\
\text { - low-maintenance system } \\
\text { - environmental friendly } \\
\text { - produce compost and can process } \\
\text { organic kitchen waste, which can } \\
\text { - } \text { Ecoduce our everyday garbage } \\
\text { - } \text { without emptying } \\
\text { dhe hormones and medicines will be } \\
\text { - easy to use in villages, in houses with } \\
\text { garden }\end{array}$ & $\begin{array}{l}\text { Weaknesses } \\
\text { - some models need electricity for } \\
\text { ventilation } \\
\text { - need to be ,fed" continuously, } \\
\text { otherwise the composting process } \\
\text { will stop } \\
\text { - do not use bowl liner so the waste } \\
\text { can stain and smear the bowl surface } \\
\text { - hard to apply in towns, densely } \\
\text { populated areas and in public } \\
\text { institutions }\end{array}$ \\
\hline $\begin{array}{l}\text { Opportunities } \\
\text { - used both in developing and } \\
\text { developed countries already } \\
\text { - can be installed places where hard to } \\
\text { approach, like underground mines } \\
\text { - the product is manageable and can be } \\
\text { processed in several ways } \\
\text { - the product can be used as a natural } \\
\text { fertilizer } \\
\text { - substitution of artificial fertilizer with } \\
\text { the composted product }\end{array}$ & $\begin{array}{l}\text { Threats } \\
\text { - } \text { spreading of flush toilets instead of it } \\
\text { - preconceptions and misconceptions } \\
\text { of utilization of human excreta for } \\
\text { agricultural purposes } \\
\text { - } \quad \text { spreading of artificial fertilizers } \\
\text { instead of composted excreta }\end{array}$ \\
\hline
\end{tabular}


Table 2: $\quad$ SWOT analysis for composting toilet which separate faeces and urine.

\begin{tabular}{|c|c|}
\hline $\begin{array}{l}\quad \text { Strengths } \\
\text { - low odour levels } \\
\text { - no need for fuel } \\
\text { - no plumbing required } \\
\text { - no emission } \\
\text { - easy to install } \\
\text { - eliminate odours and disease-bearing } \\
\text { - flies } \\
\text { - water free toilet system } \\
\text { - chemical free } \\
\text { - low-maintenance system } \\
\text { toilets can go 1-6 months without } \\
\text { emptying }\end{array}$ & $\begin{array}{l}\text { Weaknesses } \\
\text { - } \\
\text { some models need electricity for } \\
\text { ventilation } \\
\text { - need to be "fed" continuously, } \\
\text { otherwise the composting process } \\
\text { will stop } \\
\text { - do not use bowl liner so the waste can } \\
\text { stain and smear the bowl surface } \\
\text { - hard to apply in towns, densely } \\
\text { populated areas and in public } \\
\text { institutions } \\
\text { - separation of urine and faeces is not } \\
\text { suitable for real humus-forming } \\
\text { composting process } \\
\text { - during storage and transportation of } \\
\text { urine several spontaneous processes } \\
\text { such as urea hydrolysis, precipitation } \\
\text { or volatilization could change the } \\
\text { urine composition significantly } \\
\text { - storage period should be maximum } \\
\text { six months at } 20^{\circ} \mathrm{C} \text { or higher } \\
\text { - urine converted to ammonium-nitrate } \\
\text { has disadvantages like artificial } \\
\text { fertilizers contains ammonium nitrate }\end{array}$ \\
\hline $\begin{array}{l}\text { Opportunities } \\
\text { - used both in developing and } \\
\text { developed countries already } \\
\text { - can be installed places where hard to } \\
\text { approach, like underground mines } \\
\text { - the product is manageable and can be } \\
\text { processed in several ways } \\
\text { - the product (urine) can be used as a } \\
\text { natural fertilizer } \\
\text { - substitution of artificial fertilizer with } \\
\text { the urine }\end{array}$ & $\begin{array}{l}\text { Threats } \\
\text { - } \text { spreading of flush toilets instead of it } \\
\text { - } \text { preconceptions and misconceptions of } \\
\text { utilization of human excreta for } \\
\text { agricultural purposes } \\
\text { - } \text { spreading of artificial fertilizers } \\
\text { instead of urine and faeces as a } \\
\text { fertilizer }\end{array}$ \\
\hline
\end{tabular}


Table 3: $\quad$ SWOT analysis for microflush toilet.

\begin{tabular}{|c|c|}
\hline \begin{tabular}{l}
\multicolumn{1}{c}{ Strengths } \\
- \\
- no need for fuel \\
- no plumbing required \\
- no emission \\
- easy to install \\
- eliminate odours and disease-bearing \\
- flies \\
- use little amount of water \\
- chemical free \\
- low-maintenance system \\
- harvested every $2-3$ years \\
- use bowl liners, so the bowl surface \\
will stay clean that drops into the tank \\
with waste
\end{tabular} & $\begin{array}{l}\text { Weaknesses } \\
\text { - } \\
\text { some models need electricity for } \\
\text { ventilation } \\
\text { - need to be "fed" continuously, } \\
\text { otherwise the composting process will } \\
\text { stop } \\
\text { - hard to apply in towns, densely } \\
\text { populated areas and in public } \\
\text { institutions } \\
\text { - use a small amount of grey water } \\
\text { from the previous user's handwash }\end{array}$ \\
\hline $\begin{array}{l}\text { Opportunities } \\
\text { - the product is manageable and can be } \\
\text { processed in several ways } \\
\text { - the product can be used as a natural } \\
\text { fertilizer } \\
\text { - substitution of artificial fertilizer with } \\
\text { the composted product }\end{array}$ & $\begin{array}{l}\text { Threats } \\
\text { - } \text { spreading of flush toilets instead of it } \\
\text { - } \text { preconceptions and misconceptions of } \\
\text { utilization of human excreta for } \\
\text { agricultural purposes } \\
\text { - } \quad \text { spreading of artificial fertilizers } \\
\text { instead of composted human excreta }\end{array}$ \\
\hline
\end{tabular}

Table 4: $\quad$ SWOT analysis for incinerating toilet.

\begin{tabular}{|c|c|}
\hline \begin{tabular}{l}
\multicolumn{1}{c}{ Strengths } \\
- low odour levels \\
- no plumbing required \\
- easy to install \\
- eliminate odours and disease-bearing \\
flies \\
- water free toilet system \\
- chemical free \\
- low-maintenance system \\
- use bowl liners, so the bowl surface \\
will stay clean that drops into the tank \\
with waste
\end{tabular} & $\begin{array}{l}\text { Weaknesses } \\
\text { - need electricity } \\
\text { - need fuel (propane, natural gas, } \\
\text { diesel) to operate } \\
\text { - cause a minimum emission } \\
\text { - leaves minimal residue (sterile ashes) } \\
\text { - ash from incinerating toilets should } \\
\text { be disposed once per day } \\
\text { - the product - ash - is not reusable } \\
\text { - the organic matter and nutrient } \\
\text { content of excreta are wasted } \\
\text { - agricultural utilization of human } \\
\text { excreta is not possible }\end{array}$ \\
\hline $\begin{array}{l}\text { Opportunities } \\
\text { - can be installed places where hard to } \\
\text { approach, like underground mines } \\
\text { - produce electric power, it is essential } \\
\text { mostly in developing countries }\end{array}$ & $\begin{array}{l}\text { Threats } \\
\text { - } \text { spreading of flush toilets instead of it } \\
\text { - should not be installed or operated in } \\
\text { an area where there is a risk of } \\
\text { accumulation of flammable vapours } \\
\text { or dust }\end{array}$ \\
\hline
\end{tabular}




\section{Conclusion}

To sum up, we can realize that composting toilets may be safe and environmental friendly solution for utilizing human excreta, furthermore, a compost-like manageable product will be formed. Our opinion is that we have to urge the use of composting toilets which can handle faeces and urine together because they have more strengths and opportunities like any other dry toilet type. As there are other than EcoSan type technical solutions of composting toilet which can handle faeces and urine together, we would like to seek, assess and evaluate these technical solutions in more detail in the future. In villages and in garden houses the implementation of composting toilets is easy, but it is difficult in cities. The further aim of our research is to find technological solutions in cities as well.

\section{References}

[1] UNICEF \& WHO: Progress on Sanitation and Drinking Water: 2015 Update and MDG Assessment, pp. 12-17, 2015.

[2] Arslan O. \& Er I.D., SWOT analysis for safer carriage of bulk liquid chemicals in tankers. Journal of Hazardous Materials, 154(1-3), pp. 901913, 2008.

[3] Digital Library, www.tankonyvtar.hu

[4] EcoSan Waterless Toilet System, www.ecosan.co.za

[5] Országh, J., Water autarky - Sustainable water management for the world. www.eautarcie.org

[6] Jönsson, H., Baky, A., Jeppson, U., Hellström, D. \& Kärrman, E., Composition of urine, faeces, greywater and biowaste for utilization in the URWARE model. Urban water Report of the MISTRA Programme, Report 2005:6, Chalmers University of Technology, Gothenburg, Sweden, pp. 1516, 20-21, 2005.

[7] Schouw, N.L., Danteravanich, S., Mosbaek, H. \& Tjell, J.C., Composition of human excreta - a case study from Southern Thailand. Science of the Total Environment Journal 286(1-3), pp. 155-166, 2002.

[8] Vinnerås, B., Palmquist, H., Balmér, P., Weglin, J., Jensen, A., Andersson, Å., \& Jönsson, H., The characteristics of household wastewater and biodegradable waste - a proposal for new Swedish norms. Urban Water Journal 3(1), pp. 3-11, 2006.

[9] Schönning, C. \& Stenström, T.A., Guidelines for the safe Use of Urine and Faeces in Ecological Sanitation. Report 2004-1. Ecosanres, SEI. Sweden, pp. 2-7, 12-27, 2004.

[10] Feachem, R.G., Bradley, D.J., Garelick, H., \& Mara, D.D., Sanitation and Disease. Health aspects of excreta and wastewater management. World Bank studies in water supply and sanitation. John Wiley and Sons, New York, p. 501, 1983.

[11] Niwagaba, C.B., Treatment Technologies for Human Faeces and Urine, Doctoral Thesis. Swedish University of Agricultural Sciences: Uppsala, pp. 1-89, 2009. 
[12] Kirchmann, H., \& Pettersson, S., Human urine - Chemical composition and fertilizer efficiency. Fertilizer Research, 40, pp. 149-154, 1995.

[13] Höglund, C., Ashbolt, N., Stenström, T.A. \& Svensson, L.: Viral persistence in source-separated human urine. Advances in Environmental Research, 6(3), pp. 265-275, 2002.

[14] Larsen, T.A, Peters, I., Alder, A., Eggen, R., Maurer, M. \& Muncke J., Reengineering the toilet for sustainable wastewater management. Environmental Science and Technology, 35(9), pp. 192-197, 2001.

[15] Karak, T. \& Bhattacharyya, P., Human urine as a source of alternative natural fertilizer in agriculture: A flight of fancy or an achievable reality. Resources, Conservation and Recycling Vol. 55 (4), pp. 400-408, 2011.

[16] Jönsson, H., Stintzing, R., Vinnerås, B. \& Salomon, E., Guidelines on use of urine and faeces in crop production. Report 2004-2, Ecosanres, Stockholm Environment Institute: Stockholm, pp. 16-24, 2004.

[17] Maurer, M., Pronk, W. \&Larsen, T., Treatment processes for sourceseparated urine. Water Research, 40 (17), pp. 3151-3166, 2006.

[18] Pradhan, S.K., Holopainen, J.K., Weisell, J. \& Heinonen-Tanski, H., Human urine and wood ash as plant nutrients for red beet (Beta vulgaris) cultivation: impacts on yield quality. Journal of Agricultural and Food Chemistry, 58(3), pp. 2034-2039, 2010.

[19] Richert, A., Gensch, R., Jönsson, H., Stenstörm, T.A. \& Dagerskog, L., Practical guidance on the use of urine in crop production. Stockholm Environment Institute: Stockholm, pp. 10-14, 2010.

[20] Wohlsager, S., Clemens, J., Nguyet, P.T., Rechenburg, A. \& Arnold, U., Urine - valuable fertilizer with low risk after storage in the tropics. Water Environment Research, 82(9), pp. 840-847, 2010.

[21] Semalulu, O., Azuba, M., Makhosi, P. \& Lwasa, S. (2011): Potential for reuse of human urine in peri-urban farming. Innovation as key to the green revolution in Africa, pp. 651-660, 2011.

[22] Anderson, E. Turning waste into value: using human urine to enrich soils for sustainable food production in Uganda. Journal of Cleaner Production, 96, pp. 290-298, 2015.

[23] S. Mecca, H. Davis \& A. Davis, Application of GSAP Microflush toilets: a sustainable development approach to rural and peri-urban sanitation. WIT Transactions Ecology and the Environment, 175, pp. 113-122, 2013.

[24] S. Mecca, H. Davis, A. Davis, Microfranchising rural sanitation: a sustainable development model for a scale-up of a sustainable technology. WIT Transactions on Ecology and the Environment, 200, pp. 173-181, 2015.

[25] ECOJOHN, Green remote waste management solutions, www.ecojohn.com

[26] INCINOLET Electric Incinerating Toilet, www.incinolet.ca 